\title{
Vezanost za školu - analiza privrženosti školi i predanosti školskim obvezama kod srednjoškolaca
}

\section{Darko Roviš}

Nastavni zavod za javno zdravstvo Primorsko-goranske županije

Medicinski fakultet Sveučilišta Rijeci

darko.rovis@zzjzpgz.hr

\section{Petar Bezinović}

\author{
Institut za društvena istraživanja u Zagrebu \\ petar@idi.hr
}

\begin{abstract}
SAŽETAK Vezanost za školu (School bonding) se može razmatrati kroz različite oblike odnosa učenika sa školom, nastavnicima, vrijednostima i normama koje škola promiče. Kao takva ona je snažan zaštitni čimbenik za razvoj rizičnih ponašanja kojima se krše socijalne norme koje sama škola promiče.
\end{abstract}

Cilj istraživanja bio je provjeriti mjere privrženosti školi i predanosti izvršavanju školskih obveza kao dviju temeljnih dimenzija konstrukta vezanosti za školu. U tu su svrhu pripremljene odgovarajuće mjerne ljestvice u skladu s konceptualizacijom Maddox i Prinz (2003). Podaci za analizu su prikupljeni na uzorku od 1.927 adolescenata, učenica i učenika svih srednjih škola u Primorsko-goranskoj županiji.

Dvodimenzionalnost konstrukta je potvrđena faktorskom analizom. Koeficijent pouzdanost (Cronbach alfa) ljestvice Privrženosti školi od 10 tvrdnji iznosi 0,87, dok pouzdanost ljestvice Predanosti izvršavanju školskih obveza od sedam tvrdnji iznosi 0,86 . Njihova konceptualna različitost potvrđena je usporedivim regresijskim analizama s nizom prediktorskih varijabli kojima se ispitao odnos učenika prema školi. Ljestvice su provjerene i s obzirom na školski uspjeh, spol i tip škole koju učenici pohađaju. Učenici koji ostvaruju bolji školski uspjeh iskazuju višu razinu privrženosti i predanosti, dok se učenici različitih tipova škola značajnije ne razlikuju po svojoj privrženosti školi, ali se značajno razlikuju po predanosti izvršavanja školskih obveza. Djevojke općenito i učenici gimnazijskih programa iskazuju višu razinu predanosti izvršavanju školskih obveza od učenika strukovnih škola. 
Provedene analize potvrđuju valjanost razvijenih mjernih ljestvica i njihovu upotrebljivost za dalje istraživanja konstrukta vezanosti za školu na hrvatskom govornom području.

Ključne riječi: vezanost za školu, privrženost školi, predanost izvršavanju školskih obveza.

\section{Uvod}

Vezanost za školu (school bonding) predstavlja sklop stavova, emocija, motivacijskih silnica i bihevioralnih tendencija povezanih s vlastitom školom i školovanjem. Predmet je brojnih istraživanja u području obrazovanja, razvojne psihologije i istraživanja prevencije rizičnih ponašanja mladih.

Vezanost za školu ima izravan utjecaj na obrazovne ishode poput boljeg školskog uspjeha, više motivacije za učenje, većeg samopouzdanja, češćeg sudjelovanja u izvanškolskim aktivnostima i retenciju u sustavu obrazovanja (Thompson, 2006.; Waters, Cross i Runions, 2009.). Ovaj je konstrukt posebno često ispitivan u području zdravstvenih ishoda i rizičnih ponašanja učenika. Vezanost za školu pozitivno je povezana $s$ boljim fizičkim zdravljem, sudjelovanjem u fizičkim aktivnostima i zdravijom prehranom. Snažna vezanost za školu povezana je s rjeđim korištenjem sredstava ovisnosti, manjim brojem ranog stupanja u spolne odnose, s manje nasilja, suicidalnih namjera, depresije i anksioznosti. Slaba vezanost za školu, ili pak otuđenost od škole, povezana je s nizom rizičnih ponašanja poput delinkvencije, ovisnosti, napuštanja obrazovnog sustava, maloljetničkim trudnoćama, antisocijalnim ponašanjem i niskim samopouzdanjem (Hawkins i sur, 2001.; Maddox i Prinz, 2003.; Waters i sur. 2009.).

Promicanje pozitivnih vrijednosti i strukturirano učenje o svijetu, stvarnosti, sebi i drugim ljudima koje škola promovira snažno utječe na osobni i socijalni rast i razvoj mladih. Vezanost za školu se u tom kontekstu javlja kao snažan mehanizam reguliranja ponašanja i prevencije rizičnih ponašanja mladih.

Vezanost za školu možemo promatrati kroz različite aspekte odnosa učenika sa školom, nastavnicima i vrijednostima koje škola promiče. Libbey (2004.) navodi široki raspon termina i definicija koji se koriste za istraživanje i objašnjavanje ovog fenomena. Uz vezanost za školu (school bonding) srodni pojmovi koji se najčešce koriste su privrženost školi (attachment), predanost (commitment), uključenost (involvement), školsko ozračje (school climate), povezanost (connectedness) i sl. Autorica navodi čak 21 različit pristup mjerenju učeničkih odnosa u školi koje bi mogli podvesti pod zajednički naziv "povezanosti sa školom".

Procese koji stoje u podlozi razvoja vezanosti za školu i učinaka koje škola može imati na pojedinca detaljnije opisuje nekoliko utjecajnih teorija. Teorija socijalne kontrole (Social Control Theory) prva je opisala termin vezanosti za školu i obja- 
snila ponašanje pojedinca u skladu s pravilima i normama neke sredine (Hirschi, 1969.). Teorija opisuje vezanost kroz četiri dimenzije: privrženosti (attachment), predanosti (commitment), uvjerenja (beliefs) te uključenosti (involvement). Sve kasnije revizije pa i druge teorije, počivaju uglavnom na ovom modelu. Neka kasnija istraživanja potvrđuju da je privrženost školi višedimenzionalan konstrukt, u kojem se izdvajaju privrženost nastavnicima te privrženost vršnjacima i ukupnosti događaja/doživljaja u školi (Cernkovich i Giordano, 1992.; Murray i Greenberg, 2000., 2001.).

Model socijalnog razvoja (Social Development Model, Catalano i Hawkins, 1996.) svojevrsna je nadgradnja Hirschijeve teorije, te slično objašnjava prosocijalni, odnosno antisocijalni razvoj djece i mladih kroz usvajanje specifičnih obrazaca ponašanja u obitelji, školi, među vršnjacima ili u zajednici. Proces razvoja vezanosti za ove socijalne kategorije određuju prilike za aktivno i smisleno sudjelovanje u tim sustavima (opportunities), stvarni angažman koji pojedinac u njima ostvaruje (involvement), razvijenost vještina za uključivanje u te aktivnosti (skills) te nagrade i prepoznavanje koje pojedinac dobiva za svoj angažman (rewards/recognition). Prema teoriji, ključne elemente socijalne veze (bonding) čine emocionalna veza, tj. privrženost (attachment), osobna predanost (commitment) te sama uključenost u odnose (involvement). Kako je uključenost zapravo preduvjet stvaranja vezanosti za školu, samu vezanost možemo promatrati kroz preostale dvije dimenzije.

Privrženost se opisuje kroz osjećaje koje pojedinac gaji za školu i nastavnike, tj. koliko mu je stalo do škole i odnosa koje u njoj ostvaruje. Predanost možemo shvatiti kao razinu spremnosti za ulaganje vremena i truda u aktivnosti koje proizlaze iz školskih odnosa i zahtjeva. Predani učenici rado prihvaćaju školska pravila i vrijednosti, stalo im je do školskog postignuća, predani su izvršavanju školskih zadataka, pisanju domaćih zadaća, postizanju dobrih ocjena i učenju. U ovakvom shvaćanju predanost sadrži uvjerenja koja škola promiče (beliefs) te s time povezanih ponašanja. Stoga se uvjerenja i vrijednosti koje škola promiče najčešće ne promatraju kao zasebna dimenzija vezanosti uz školu (Cernkovich i Giordano, 1992.).

Prema ovoj teoriji socijalnog razvoja, dva najvažnija prekursora za stvaranje vezanosti za školu su (1) prilike za uključivanje u školske aktivnosti i odnose te (2) osobne vještine za sudjelovanje u njima. Prilike za uključivanje i relevantne vještine određene su cijelim nizom različitih vanjskih utjecaja, poput individualnih obilježja učenika (npr. samokontrole, dobi, spola i dr.), obiteljskih odnosa, nastavničkog stila poučavanja i različitih školskih politika. Veliki je broj istraživanja potvrdio kako je višu razinu vezanosti za školu moguće očekivati u sigurnom i brižnom okruženju (Murray i Greenberg, 2001.), u razvojno primjerenom, strukturiranom i poticajnom okruženju (Eccles i Roeser, 2003.), u okruženju u kojemu se postavljaju jasna i visoka očekivanja od učenika te u kojemu postoje jasna i dosljedno primjenjivana pravila ponašanja i discipliniranja (Cunningham, 2007.; Klem i Connell, 2004.). Abbott i O Donnell (1998.) kao i Klem i Connell (2004.) navode kako su jednake prilike za uključivanje u nastavni proces za sve učenike 
te pozitivni, podržavajući i recipročni odnosi nastavnik-učenik ključni za razvoj dobre vezanosti za školu.

Prema literaturi, postoji nekoliko moderatora ovih procesa. Poznato je kako razina vezanosti za školu opada s kronološkom dobi (Simons-Morton i sur., 1999.). Starijim je učenicima emocionalni odnos sa školom manje važan nego djeci. Cernkovich i Giordano (1992.) nadalje ističu kako djevojke iskazuju višu razinu vezanosti za školu od mladića, a navode i kako postoje značajne razlike u važnosti pojedinih dimenzija vezanosti za školu između spolova. U literaturi je malo poznato kako na vezanost za školu utječe tip škole koju učenik pohađa. Realno je očekivati da unutar različitih školskih sredina zbog različitog školskog konteksta, npr. privatne-javne škole ili demografske kompozicije škole, postoje značajne razlike u prihvaćanju škole i vezanosti za školu. Uz ovakvu diferencijaciju tipova škole često se vezuje i socioekonomski status obitelji koji može djelovati kao moderator razvoja vezanosti za školu (Mcgee, 1992.).

Ovaj se niz okolnosti koje određuju intenzitet vezanosti za školu zasigurno odnosi i na situaciju u hrvatskim školama. Neujednačeni uvjeti rada u različitim školama, velika heterogenost okruženja iz kojih učenici dolaze, razlike u pristupu učenju i poučavanju u različitim tipovima srednjih škola (trogodišnje i četverogodišnje strukovne škole, umjetničke škole, gimnazije), različita psihološko-pedagoška pripremljenost nastavnika ili različita školska kultura, samo su neki od mogućih čimbenika koji mogu određivati odnos i emocionalni stav učenika prema školi.

Kvaliteta istraživanja u području vezanosti za školu tijesno je određena kvalitetom mjernih postupaka koji se koriste za istraživanje konstrukta. Maddox i Prinz (2003.) u svom pregledu područja ističu problem nepostojanja posebnih instrumenta i mjera kreiranih i namijenjenih isključivo istraživanjima vezanosti učenika za školu, a veliki broj srodnih, često i preklapajućih naziva i definicija stvaraju dodatne teškoće (Libbey, 2004.). Većina istraživanja koja su određena najutjecajnijim teorijskim okvirima (Hirschi, 1969.; Catallano i Hawkins, 1996.) koristi se svega s nekoliko varijabli koje reprezentiraju čitav konstrukt, poput: Volim svoju školu; Sviđaju mi se nastavni predmeti; Ponosan sam na svoju školu. Lonzak i sur. (2001.) vezanost za školu mjere s tri čestice koje opisuju koliko dijete voli svoju školu, učitelje i nastavu. Hawkins i sur. (2001.) koriste pet čestica: Volim školu; Ujutro najčešće volim ići u školu; Samoinicijativno radim dodatne poslove za školu; Zadatke odrađujem dok ih ne završim te Sviđaju mi se nastavni predmeti. Cunningham (2007.) za mjerenje privrženosti koristi čestice poput: Ljudima u školi je stalo do mene ili Osjećam da pripadam školi, dok za predanost koristi Trudim se na nastavi; Obično poštujem školska pravila. Wenzel, Weichold i Silbereisen (2009.) dvije dimenzije vezanosti za školu mjere s devet čestica koje uključuju: Volim ići u školu; Jedva čekam trenutak kad neću morati iči u školu; Volim učiti; Uškoli učimo zanimljive stvari ili Osjećam se ugodno za vrijeme nastave.

U hrvatskoj literaturi ne nalazimo posebna istraživanja vezanosti za školu, pa tako niti instrumentarij kojim bi se vezanost za školu mjerila. Nalazimo tek parcijalne mjere dijela odnosa koje učenik doživljava u školi poput procjena vršnjačkog nasi- 
lja, osjećaja bliskosti s vršnjacima ili zadovoljstva i opterećenosti školom (Kuzman, Pejnović Franelić i Pavić Šimetin, 2008.; Bezinović, 2010.; Miharija i Kuridža, 2010.).

Cilj ovog istraživanja je analiza instrumenta za provjeru konstrukta vezanosti za školu, specifično privrženosti školi i predanosti izvršavanju školskih obveza, u hrvatskom srednjoškolskom obrazovanju. Smatramo važnim provjeriti odnos ovih konstrukata sa školskim i demografskim faktorima s kojima postoji opisana teorijski utemeljena povezanost.

\section{Metoda}

\section{Sudionici}

Istraživanje je provedeno na proporcionalnom stratificiranom slučajnom uzorku učenika svih srednjih škola u Primorsko-goranskoj županiji (30 škola s ukupno 10.770 učenika). Ispitan je proporcionalan broj učenika trogodišnjih strukovnih škola, četverogodišnjih strukovnih škola i gimnazija. Uzorak je odabran na način da je u svakoj školi na osnovi podataka o broju upisanih učenika u svim razrednim odjelima uključeno po $20 \%$ učenika svih razreda prema slučajnom odabiru. Za randomizaciju uzorka korišten je program za generiranje slučajnih brojeva "Research randomizer" (www.randomizer.org). Ukupno je ispitano 1.927 učenika (89,5\% odziva), 991 mladić $(51,4 \%)$ i $936(48,6 \%)$ djevojaka. Ispitano je 324 učenika trogodišnjih strukovnih škola (16,8\%), 1.066 učenika četverogodišnjih strukovnih škola (55,3\%) i 537 učenika gimnazijskih programa (27,9\%).

\section{Mjerni postupci}

Primijenjen je upitnik pod nazivom "Kako si?" koji se koristi za praćenje rizičnih ponašanja učenika u Primorsko-goranskoj županiji od 2001. godine. Uz zastupljenost različitih oblika rizičnih ponašanja, upitnikom su ispitana i školska iskustva učenika i njihovo viđenje škole. U analizu su uvrštena dva seta pitanja kojima se ispituju: (1) vezanost za školu i (2) utjecaj škole - odnosno školska iskustva koja potencijalno mogu utjecati na stavove, osjećaje i ponašanja učenika vezana uz školu.

\section{(1) Vezanost za školu}

Za ispitivanje vezanosti za školu korišteno je 17 tvrdnji za koje se pretpostavljalo da ispituju dva ključna faktora: Privrženost školi i Predanost izvršavanju školskih obveza ${ }^{1}$. Čestice obuhvaćaju učeničke procjene emocionalne vezanosti za školu te

\footnotetext{
1 U nastavku se za opis ovih dviju varijabli koriste skraćeni oblici naziva - "Privrženost" i
} "Predanost". 
procjene uspješnosti obavljanja školskih zadataka i uloženog truda. Ove se mjere javljaju i u drugim istraživanjima vezanosti za školu (Hawkins i sur., 2001.; Lonczak i sur., 2001.; Cunningham, 2007.; Wenzel i sur. 2009.). Ispitanici su svoje procjene iskazivali na ljestvici učestalosti od četiri stupnja (0 - "nikad"; 1 - "rijetko"; 2 - "često"; 3 - "vrlo često"). Isti format procjenjivanja korišten je i za sve preostale, dolje opisane ljestvice (osim za Poticajnost škole).

Privrženosti školi (Attachment to school) je ispitana ljestvicom od 10 tvrdnji koje pokrivaju osnovne teorijske pretpostavke konstrukta. Pouzdanost ljestvice (Cronbach alfa) iznosi 0,87.

Predanosti izvršavanju školskih obveza (Commitment to school) je ispitana sa sedam teorijski dobro postuliranih tvrdnji. Pouzdanost ove ljestvice (Cronbach alfa) iznosi 0,86 .

Kako se ljestvice sastoje od različitog broja tvrdnji, obje su linearno transformirane na zajedničku mjernu ljestvicu od 0 do 100, što omogućuje neposredno uočavanje razlika u njihovim prosječnim vrijednostima.

Faktorska struktura i detaljan opis obiju ljestvica prikazan je u rubrici Rezultati.

\section{(2) Utjecaj škole}

Utjecaj škole ispitan je sa sedam varijabli koje opisuju različita školska iskustva i školsko okruženje, a za koje se pretpostavlja da smisleno koreliraju s aspektima vezanosti za školu te tako podržavaju teorijsko konceptualiziranje konstrukta. Ove varijable relevantnima smatraju različiti autori, Lonczak i sur. (2001.), Maddox i Prinz (2003.), Libbey (2004.), Waters i sur. (2009.).

Sve su varijable kreirane kao nezavisne ljestvice, a detaljan sadržaj ljestvica i faktorska struktura svih korištenih tvrdnji prikazani su u Dodatku ovoga rada. Ukupan rezultat svake ljestvice određen je zbrojem procjena na svim tvrdnjama. Kako se i ove ljestvice sastoje od različitog broja tvrdnji, sve su varijable linearno transformirane na zajedničku mjernu ljestvicu od 0 do 100, što omogućuje neposredno uočavanje razlika u njihovim prosječnim vrijednostima.

Poticajnost škole (Cronbach alfa=0,88). Ispituje se ljestvicom za procjenu razine poticanja 13 aspekata osobnog, kognitivnog i socijalnog razvoja učenika, a za koje se očekuje da se moraju ostvarivati u sklopu školskog obrazovanja. Primjeri ispitanih aspekata: (Škola potiče) Razvoj osobnog morala, etičkog sustava vrijednosti, Jasno i dobro usmeno i pismeno izražavanje, Samostalno i kritičko razmišljanje... Ispitanici su iskazivali svoj stupanj slaganja s pojedinim tvrdnjama na ljestvici od četiri stupnja (0 - "uopće ne"; 1 - "uglavnom ne"; 2 - "uglavnom da"; 3 - "u potpunosti da"). 
Pobvaljivanje i podrška (Cronbach alfa=0,85). Ljestvica se sastoji od osam tvrdnji kojima se procjenjuje učestalost primanja pohvala za trud, uspješnost u obavljanju zadataka te učestalost komunikacije s nastavnicama koja je u funkciji podrške samoinicijativnosti učenika. Primjeri tvrdnji: Kad u školi uspješno izvršim zadatak ili kad ostvarim neki uspjeh dobivam pohvalu od nastavnika, Nastavnici me nagrade kad uložim poseban trud, Nastavnici me potiču na inicijativu i angažman u nastavi i izvan nastave...

Uključenost u nastavi i učenju (Cronbach alfa=0,74). Ljestvica se sastoji od sedam tvrdnji kojima se procjenjuje angažman učenika na nastavi i u učenju. Slijedi ideju da je angažiranost na nastavi i u učenju osnovno obilježje aktivnog učenja te da ono odražava uspješnost vođenja nastavnog sata i motiviranja učenika od strane nastavnika. Primjeri tvrdnji: Na samoj nastavi sam u grupi radio s drugim učenicima na nekom zadatku, Na nastavi sam postavljao pitanja $i$ sudjelovao $u$ grupnim raspravama, $S$ učenicima iz razreda sam $i$ izvan nastave surađivao na školskim zadacima...

Školska pravila i dodatne aktivnosti (Cronbach alfa=0,74). Ljestvica se sastoji od pet tvrdnji kojima se ispituje dosljednost školskih pravila i prisutnost dodatnih aktivnosti. Primjeri tvrdnji: U školi postoje jasna pravila ponašanja $i$ disciplinske mjere, Školska pravila $i$ disciplinske mjere se primjenjuju dosljedno i pošteno, U školi ima dovoljno izvannastavnih aktivnosti u koje se mogu uključiti...

U analizu su uključene i tri ljestvice kojima se mjere negativni aspekti školskih iskustava koja bi mogla priječiti razvoj pozitivne vezanosti za školu i djelovati demotivirajuće na izvršavanje školskih obveza.

Strab od škole (Cronbach alfa=0,83). Ljestvica se sastoji od šest tvrdnji kojima se iskazuje strah od nastavnika, ispitivanja, loših ocjena, reakcija roditelja. Primjeri tvrdnji: Bojim se neuspjeha u školi, Nastavnici u meni izazivaju strah, Bojim se roditeljskib reakcija na moje ocjene...

Osjećaj nekompetentnosti za školu (Cronbach alfa=0,78). Ljestvica se sastoji od pet tvrdnji koje ispituju osjećaj nesposobnosti za zadovoljavanje zahtjeva škole, probleme s razumijevanjem školskih sadržaja, obeshrabrenosti i razmišljanje o smislu školovanja. Primjeri tvrdnji: Školske obveze su za mene preteške, Školski program je prezabtjevan za mene, Razmišljam o prestanku školovanja...

Iskustva fizičkog nasilja (Bullying), (Cronbach alfa=0,74). Ljestvica se sastoji od pet tvrdnji koje ispituju učestalost iskustava fizičkog zlostavljanja od strane drugih učenika. Primjeri tvrdnji: Netko me je fizički napao u školi, U školi su mi neki učenici prijetili da će me istući, Drugi učenici su me fizički maltretirali (gurkali, tukli isl.)... 


\section{Postupak}

Istraživanje je provedeno početkom 2010. godine u svim srednjim školama u Primorsko-goranskoj županiji (PGŽ). Potaknuo ga je Upravni odjel za zdravstvenu zaštitu i socijalnu skrb PGŽ, a odobrio osnivač škola - Upravni odjel za obrazovanje, kulturu i sport PGŽ. Istraživanje je provedeno u suglasju s odredbama Etičkog kodeksa istraživanja s djecom (2003.). Primjena upitnika provedena je u školama, u manjim skupinama do 25 učenika. Sudionici su prije primjene upitnika bili upoznati sa svrhom i ciljevima istraživanja. Upućeni su da je sudjelovanje anonimno i dragovoljno te da mogu odustati kad god to požele. Niti jedan sudionik nije odbio svoje sudjelovanje. Primjenu upitnika su proveli posebno obučeni suradnici, studenti psihologije.

\section{Obrada podataka}

Eksploratornom analizom glavnih komponenti utvrđena je dimenzionalnost konstrukta Vezanosti za školu. Ova je struktura provjerena i konfirmatornom faktorskom analizom. Jednosmjernim analizama varijance provjerene su razlike u privrženosti i predanosti s obzirom na školski uspjeh i dob učenika. Dvosmjernim analizama varijance provjereni su efekti spola i tipa škole na privrženost i predanost, a regresijskim su analizama provjereni odnosi preostalih školskih varijabli (u Metodi opisanih kao Utjecaj škole) na privrženost i predanost.

\section{Rezultati}

\section{Struktura vezanosti za školu}

Faktorska struktura tvrdnji koje ispituju privrženost školi i predanost izvršavanju školskih obveza provedena je na 17 tvrdnji za koje se pretpostavljalo da mjere ova dva konstrukta.

Provedena je analiza glavnih komponenti s Varimax ortogonalnom rotacijom. Kaiser-Meyer-Olkinov indeks od 0,93 kao mjera adekvatnosti korelacijske matrice za faktorsku analizu, pokazuje pogodnost polaznih podataka za analizu (Fulgosi, 1979). Ekstrahirane su dvije glavne komponente s Eigen-vrijednosti većom od 1 (Guttman-Kaiserov kriterij za ekstrakciju faktora). Te dvije komponente objašnjavanju 50,6\% varijance svih 17 tvrdnji.

Rotirana matrica glavnih komponente prikazana je u Tablici 1. U matrici su prikazana samo koeficijenti veći od 0,30. 
Tablica 1.

Struktura faktora Vezanosti za školu

\begin{tabular}{|l|c|c|}
\hline Tvrdnje & F1 & F2 \\
\hline Zadovoljan sam svojim nastavnicima & 0,78 & \\
\hline Nastavnici nas poštuju i pažljivi su prema nama & 0,73 & \\
\hline Ostvarujem dobru komunikaciju s nastavnicima & 0,69 & \\
\hline Moji nastavnici potiču kreativnost učenika & 0,68 & \\
\hline Škola me potiče na razmišljanje i stvaranje novih ideja & 0,66 & \\
\hline Nastavnici su zainteresirani za predmet koji predaju & 0,66 & \\
\hline Sadržaj većine predmeta je zanimljiv & 0,64 & \\
\hline Nastavnici uvažavaju mišljenje i ideje učenika & 0,62 & \\
\hline Ova škola ispunjava moja očekivanja & 0,59 & \\
\hline Volim ići u školu & 0,46 & \\
\hline Redovito učim & & 0,80 \\
\hline Uvijek nađem vremena za učenje & & 0,76 \\
\hline Kada nam je najavljen usmeni ili pismeni ispit, planiram kada ću i koliko učiti & & 0,74 \\
\hline Trudim se biti što bolji učenik & & 0,71 \\
\hline Redovito pišem domaće zadaće & & 0,69 \\
\hline Dobro planiram svoje dnevne obveze i aktivnosti & 0,67 \\
\hline Dobro znam rasporediti slobodne aktivnosti i učenje tako da sve stignem & 0,66 \\
\hline
\end{tabular}

Iz tablice je uočljiva čista dvofaktorska solucija. Prvi se faktor od deset tvrdnji odnosi na pozitivan emocionalni odnos prema školi i nastavnicima i nazivamo ga faktorom Privrženosti školi. Vezan je uz pozitivna iskustva prihvaćanja od strane nastavnika, zanimljivosti ponuđenih sadržaja, slobode osobnog iskazivanja mišljenja, kreativnosti i ideja. Drugi faktor se sastoji od sedam tvrdnji koje opisuju revnost u izvršavanja školskih obveza te ga nazivamo faktorom Predanosti izvršavanju školskih obveza. Vezan je uz redovitost učenja i pisanja zadaća, dobru organizaciju vremena i planiranje učenja te uloženi trud u ostvarivanje što boljeg školskog uspjeha.

Tvrdnja koja u drugim istraživanjima često jedina predstavlja mjeru vezanosti za školu, Volim ići u školu, ima najmanje faktorsko opterećenje u prvom faktoru. Ovo se može objasniti činjenicom da sama tvrdnja Volim iči u školu odražava poopćeni stav koji ne mora biti u visokim korelacijama sa specifičnim školskim iskustvima koje ispituju preostale tvrdnje u faktoru.

Dvodimenzionalnost konstrukta Vezanosti za školu je provjerena i konfirmatornom faktorskom analizom. Slaganje s ovim dvofaktorskim rješenjem provjereno je s dva indeksa podudarnosti. 
Prvi je indeks apsolutne podudarnosti (absolute fit indices) SRMS (standardized root mean square residual) koji iznosi 0,034. SRMS preporučuju Hu i Bentler (1998.) zbog njegove osjetljivosti na loše specifikacije jednostavnih modela. Preporučena vrijednost za prihvaćanje modela trebala biti niža od 0,08. Drugi je indeks često korišteni Jöreskog GFI (goodness-of-fit index) koji iznosi 0,97, a čija bi vrijednost za dobro podudaranje trebala iznositi više od 0,95 (Sun, 2005.).

Oba indeksa podudarnosti potvrđuju testiranu dvofaktorsku soluciju korištenih tvrdnji, tako da se može zaključiti da Privrženost školi i Predanost izvršavanju školskih obveza predstavljaju dva konceptualno različita konstrukta.

\section{Privrženost, predanost i školski uspjeh}

Odnos između školskog uspjeha i privrženosti, odnosno predanosti provjeren je jednosmjernom analizom varijance. Uspoređene su procjene privrženosti i predanosti s obzirom školski uspjeh učenika na polugodištu tekuće školske godine. Uspjeh je iskazan ocjenama od 1 do 5. Rezultati analiza prikazani su u Tablici 2.

Tablica 2.

Prosječne procjene privrženosti i predanosti s obzirom na školski uspjeh

\begin{tabular}{|c|c|c|c|}
\cline { 3 - 4 } \multicolumn{2}{c|}{} & \multicolumn{2}{c|}{ Privrženost } \\
\hline $\begin{array}{c}\text { Školski } \\
\text { uspjeh }\end{array}$ & N & M & SD \\
\hline 1 & 264 & 7,44 & 18,34 \\
\hline 2 & 45 & 36,00 & 17,24 \\
\hline 3 & 439 & 40,39 & 16,25 \\
\hline 4 & 687 & 48,36 & 17,34 \\
\hline 5 & 162 & 55,27 & 18,37 \\
\hline \multicolumn{3}{|c|}{$\mathrm{F}(4,1596)=43,96 ; \mathrm{p}<0,001$} \\
\hline
\end{tabular}

\begin{tabular}{|c|c|c|c|}
\cline { 3 - 4 } \multicolumn{2}{c|}{} & \multicolumn{2}{c|}{ Predanost } \\
\hline $\begin{array}{c}\text { Školski } \\
\text { uspjeh }\end{array}$ & $\mathbf{N}$ & $\mathbf{M}$ & SD \\
\hline 1 & 257 & 38,06 & 20,99 \\
\hline 2 & 48 & 38,29 & 21,32 \\
\hline 3 & 436 & 42,79 & 19,79 \\
\hline 4 & 682 & 54,12 & 19,91 \\
\hline 5 & 163 & 68,13 & 23,19 \\
\hline \multicolumn{3}{|c|}{$\mathrm{F}(4,1596)=77,87 ; \mathrm{p}<0,001$} \\
\hline
\end{tabular}

Za oba ispitana faktora pokazuje se statistički značajna razlika s obzirom na školski uspjeh. Učenici s boljim školskim uspjehom iskazuju veću privrženost školi, i još veću, izraženiju predanost izvršavanju školskih obveza što se može uočiti iz F-omjera.

Post-hoc analize (Newman-Keuls-ov postupak) pokazuju preciznije, da se ova značajnost razlika ne odnosi na učenike s nedovoljnim, dovoljnim i dobrim uspjehom koji se međusobno ne razlikuju. Ova se skupina "lošijih" učenika značajno razlikuje od učenika koji ostvaruju vrlo dobar uspjeh, a ovi se pak isto tako značajno razlikuju od učenika koji ostvaruju odličan uspjeh. Odlični učenici iskazuju zna- 
čajno višu razinu privrženosti i predanosti školi od učenika koji ostvaruju lošiji školski uspjeh.

\section{Privrženost, predanost $i$ dob}

Dobne razlike u privrženosti i predanosti također su ispitane jednosmjernom analizom varijance, gdje su kao grubi pokazatelji dobi učenika, korištene kategorije razreda kojega učenik pohađa. Rezultati dviju analiza prikazani su u Tablici 3.

Tablica 3.

Prosječne procjene privrženosti i predanosti s obzirom na dob (razred)

\begin{tabular}{|c|c|c|c|}
\cline { 3 - 4 } \multicolumn{2}{c|}{} & \multicolumn{2}{c|}{ Privrženost } \\
\hline Razred & N & M & SD \\
\hline 1 & 488 & 45,78 & 18,27 \\
\hline 2 & 471 & 44,37 & 17,57 \\
\hline 3 & 485 & 43,95 & 19,20 \\
\hline 4 & 380 & 44,79 & 17,21 \\
\hline \multicolumn{3}{|c|}{$\mathrm{F}(3,1824)=0,91 ; \mathrm{p}=0,435$} \\
\hline
\end{tabular}

\begin{tabular}{|c|c|c|c|}
\cline { 3 - 4 } \multicolumn{2}{c|}{} & \multicolumn{2}{c|}{ Predanost } \\
\hline Razred & $\mathbf{N}$ & $\mathbf{M}$ & SD \\
\hline 1 & 486 & 52,31 & 3,03 \\
\hline 2 & 477 & 51,02 & 22,20 \\
\hline 3 & 480 & 47,10 & 22,85 \\
\hline 4 & 379 & 48,50 & 21,11 \\
\hline \multicolumn{3}{|c|}{$\mathrm{F}(3,1821)=5,27 ; \mathrm{p}=0,001$} \\
\hline
\end{tabular}

Rezultati pokazuju da ne postoji statistički značajna razlika u privrženosti školi između učenika različite dobi, odnosno različitih razreda. Učenici od prvog do četvrtog razreda srednje škole u ispitanom uzorku iskazuju podjednaku razinu privrženosti školi. Situacija je ponešto različita s obzirom na predanost. Učenici nižih razreda iskazuju ponešto višu razinu predanosti za izvršavanje školskih obveza od starijih učenika.

Post-hoc analiza (Newman-Keuls-ov postupak) pokazuje preciznije, da se ova značajnost razlike odnosi na učenike prvih i drugih razreda, koji iskazuju značajno višu razinu predanosti izvršavanju školskih obveza od učenika trećih i četvrtih razreda.

\section{Rodne razlike u privrženosti i predanosti učenika različitih tipova škola}

S ciljem utvrđivanja razlika u privrženosti i predanosti djevojaka i mladića koji pohađaju različite tipove škola, provedena je dvosmjerna analiza varijance kojom je ispitan efekt spola i tipa škole na privrženost i predanost učenika. Prosječne vrijednosti procjena na ljestvicama Privrženosti i Predanosti prikazane su u Tablicama 4. i 5. i na Slikama 1. i 2. 
Tablica 4.

Prosječne procjene privrženosti djevojaka i mladića s obzirom na tip škole

\begin{tabular}{|l|c|c|c|c|}
\hline \multirow{2}{*}{ Tip škole } & spol & N & M & sd \\
\hline \multirow{2}{*}{ 3. god. strukovna škola } & $\mathrm{M}$ & 233 & 43,93 & 19,63 \\
\cline { 2 - 5 } & $\check{Z}$ & 70 & 46,00 & 20,05 \\
\hline \multirow{2}{*}{ 4. god. strukovna škola } & $\mathrm{M}$ & 510 & 42,26 & 18,39 \\
\cline { 2 - 5 } & $\check{Z}$ & 506 & 44,53 & 18,56 \\
\hline \multirow{2}{*}{ gimnazija } & $\mathrm{M}$ & 195 & 47,85 & 17,27 \\
\cline { 2 - 5 } & $\check{Z}$ & 323 & 47,23 & 15,34 \\
\hline
\end{tabular}

Slika 1.

Prosječne vrijednosti procjena na ljestvici Privrženosti u uzorcima mladića i djevojaka, učenika različitih tipova škola

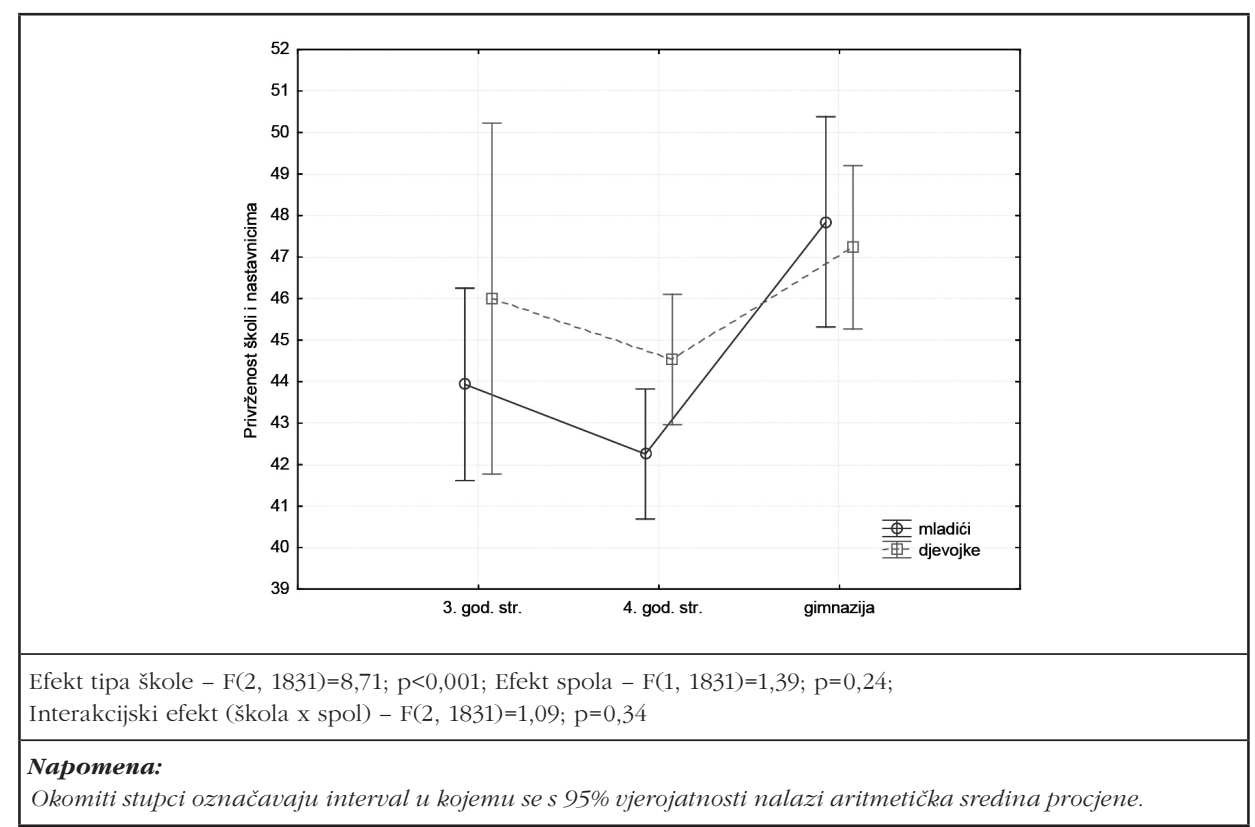

Rezultati upućuju na značajan efekt tipa škole, ali ne i na značajan efekt spola, niti na značajan interakcijski efekt dviju varijabli. Post-hoc analiza (Newman-Keuls-ov postupak) pokazuje da jedina značajna razlika postoji između procjena mladića u četverogodišnjim strukovnim školama u odnosu na mladiće i djevojke u gimnazijama. Iz slike je uočljiv izrazito veliki raspon u kojemu se mogu nalaziti aritmetičke sredine procjena, što upućuje na izrazito veliki varijabilitet procjena privrženosti školi, posebice kod djevojaka u trogodišnjim strukovnim školama. 
Tablica 5.

Prosječne procjene Predanosti djevojaka i mladića s obzirom na tip škole

\begin{tabular}{|l|c|c|c|c|}
\hline \multirow{2}{*}{ Tip škole } & spol & N & M & sd \\
\hline \multirow{3}{*}{ 3. god. strukovna škola } & $\mathrm{M}$ & 228 & 42,11 & 22,77 \\
\cline { 2 - 5 } & $\check{Z}$ & 72 & 44,71 & 25,76 \\
\hline \multirow{2}{*}{ 4. god. strukovna škola } & $\mathrm{M}$ & 514 & 44,81 & 20,80 \\
\cline { 2 - 5 } & $\check{Z}$ & 504 & 51,94 & 22,02 \\
\hline \multirow{2}{*}{ gimnazija } & $\mathrm{M}$ & 193 & 53,59 & 22,59 \\
\cline { 2 - 5 } & $\check{Z}$ & 322 & 58,42 & 20,79 \\
\hline
\end{tabular}

\section{Slika 2.}

Prosječne vrijednosti procjena na ljestvici Predanosti u uzorcima mladića i djevojaka, učenika raznih tipova škola

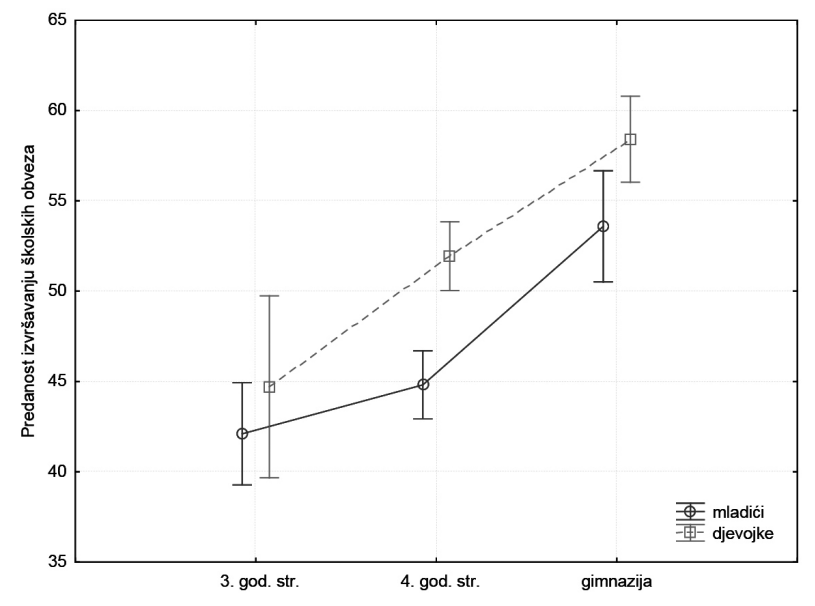

Efekt tipa škole $-\mathrm{F}(2,1827)=31,14 ; \mathrm{p}<0,001 ;$ Efekt spola $-\mathrm{F}(1,1827)=14,63 ; \mathrm{p}<0,001 ;$

Interakcijski efekt (škola x spol) - F(2, 1827) $=1,18 ; \mathrm{p}=0,31$

Što se predanosti tiče, statistički se značajnim pokazuju efekti tipa škole i spola učenika, no ne i interakcijski efekt dviju varijabli. Najnižu razinu predanosti iskazuju učenici trogodišnjih strukovnih škola, a najvišu učenici gimnazija. Općenito se može reći da djevojke iskazuju značajno veću predanost izvršavanju školskih obveza od mladića.

Post-hoc analiza (Newman-Keuls postupak) pokazuje da među procjenama mladića i djevojaka u trogodišnjim strukovnim školama i mladića u četverogodiš- 
njim strukovnim školama ne postoje međusobno značajne razlike. Ove skupine učenika značajno nižom procjenjuju svoju predanost izvršavanju školskih obveza u odnosu na učenice četverogodišnjih strukovnih škola te na učenike i učenice gimnazijskih programa. Najveću predanost učenju iskazuju djevojke gimnazijalke, čije se procjene značajno razlikuju od svih ostalih podskupina učenika.

Podaci prikazanih analiza varijance odražavaju različite odnose varijabli spola i tipa škole u odnosu na iskazane razine privrženosti i predanosti te potvrđuju konceptualnu različitost konstrukata Privrženosti i Predanosti.

\section{Privrženost i predanost u kontekstu ostalih školskih varijabli}

Da bi se dodatno provjerila konceptualna sličnost/različitost konstrukata Privrženosti i Predanosti kao osnovnih dimenzija vezanosti za školu, provedene su dvije usporedive multiple regresijske analize pri čemu su Privrženost u prvoj, a Predanost u drugoj analizi tretirane kao "kriterijske" varijable u odnosu prema identičnom setu "prediktorskih" varijabli relevantnih za školski kontekst.

Prikaz korištenih varijabli i njihovih deskriptivnih podataka nalazi se u Tablici 6.

Tablica 6.

Deskriptivni podaci svih varijabli uključenih u regresijske analize $(\mathrm{N}=1.251)$

\begin{tabular}{|l|c|c|c|}
\hline Vezanost za školu & M & sd & $\alpha$ \\
\hline Privrženost školi i nastavnicima & 44,52 & 18,05 & 0,87 \\
\hline Predanost izvršavanju školskih obveza & 49,90 & 22,07 & 0,86 \\
\hline Utjecaj škole i školski faktori & & & \\
\hline Poticajnost škole & 52,25 & 18,05 & 0,88 \\
\hline Školska pravila i dodatne aktivnosti & 41,89 & 19,88 & 0,80 \\
\hline Strah od škole & 38,22 & 22,76 & 0,83 \\
\hline Uključenost u nastavi & 36,98 & 16,29 & 0,74 \\
\hline Pohvaljivanje i podrška & 34,54 & 18,83 & 0,85 \\
\hline Osjećaj nekompetentnosti za školu & 23,60 & 18,80 & 0,78 \\
\hline Fizičko nasilje (bullying) & 7,771 & 11,63 & 0,74 \\
\hline Školski uspjeh na polugodištu & 3,32 & 1,19 & \\
\hline
\end{tabular}

U Tablici 7. su prikazane korelacije između ispitanih varijabli. 
Tablica 7.

Korelacije Privrženosti, Predanosti i prediktorskih varijabli

\begin{tabular}{|c|c|c|c|c|c|c|c|c|c|}
\hline & PRIV & PRED & $\mathrm{PO}$ & PŠ & ŠP & UK & Šs & ON & FZ \\
\hline Predanost (PRED) & $0,50^{* *}$ & & & & & & & & \\
\hline Pohvaljivanje i podrška (PO) & $0,65^{* *}$ & $0,35^{* *}$ & & & & & & & \\
\hline Poticajnost škole (PŠ) & $0,53^{* *}$ & $0, \mathbf{4 1} * *$ & $0,45^{\text {*** }}$ & & & & & & \\
\hline Školska pravila i dodatne aktivnosti (ŠP) & $0,48^{* *}$ & $0,35^{* *}$ & $0,48^{* * *}$ & $0,42^{\text {*** }}$ & & & & & \\
\hline Uključenost u nastavi (UK) & $0,42^{* *}$ & $0,42^{* *}$ & $0,41^{* * *}$ & $0,36^{* * *}$ & $0,29^{* * *}$ & & & & \\
\hline Strah od škole (SŠ) & $-0,06^{* * *}$ & $0,15^{* * *}$ & $-0,03$ & 0,03 & 0,03 & $0,12^{* * *}$ & & & \\
\hline Osjećaj nekompetentnosti (ON) & $-0,26^{* * *}$ & $-0,12^{* *}$ & $-0,12^{* * *}$ & $-0,13^{\text {**a }}$ & $-0,03$ & $-0,09^{\text {*k }}$ & $0,36^{\text {*** }}$ & & \\
\hline Fizičko zlostavljanje (FZ) & $-0,16^{* *}$ & $-0,11^{* * *}$ & $-0,03$ & $-0,09^{* *}$ & $-0,10^{\text {*** }}$ & 0,00 & $0,12^{\text {*** }}$ & $0,16^{\text {*** }}$ & \\
\hline Školski uspjeh & $0,29^{* * *}$ & $0,37^{* *}$ & $0,22^{* * *}$ & $0,18^{* * *}$ & $0,18^{\text {**** }}$ & $0,31^{\text {k*k }}$ & $-0,07^{\text {***** }}$ & $-0,23^{\text {***k }}$ & $-0,11^{\text {*** }}$ \\
\hline
\end{tabular}

PRIV=Privrženost; ${ }^{* *} \mathrm{p} \leq .01$

Rezultati provedene multiple regresijske analize prikazani su u Tablici 8.

Tablica 8.

Rezultati regresijskih analiza

\begin{tabular}{|c|c|c|c|c|c|c|c|c|c|}
\hline \multicolumn{5}{|c|}{ Prediktori Privrženosti školi i nastavnicima } & \multicolumn{5}{|c|}{ Prediktori Predanosti izvršavanju školskih obveza } \\
\hline Prediktori & Beta & $\mathbf{t}$ & $\mathbf{p}$ & $\mathbf{r}_{\text {parc }}$ & Prediktori & Beta & $\mathbf{t}$ & $\mathbf{p}$ & $\mathbf{r}_{\text {parc }}$ \\
\hline \multirow{2}{*}{$\begin{array}{l}\text { Pohvaljivanje i } \\
\text { podrška }\end{array}$} & \multirow{2}{*}{, 415 } & \multirow{2}{*}{17,36} & \multirow{2}{*}{0,00} & \multirow{2}{*}{0,44} & Školski uspjeh &, 245 & 9,85 & 0,00 & 0,27 \\
\hline & & & & & Poticajnost škole & 200 & 7,28 & 0,00 & 0,20 \\
\hline Poticajnost škole &, 212 & 9,41 & 0,00 & 0,26 & \multirow{2}{*}{ Uključenost u nastavi } & \multirow{2}{*}{,192 } & \multirow{2}{*}{7,14} & \multirow{2}{*}{0,00} & 0,20 \\
\hline \multirow{2}{*}{$\begin{array}{l}\text { Školska pravila i } \\
\text { dodatne aktivnosti }\end{array}$} & \multirow[t]{2}{*}{,148 } & \multirow[t]{2}{*}{6,52} & \multirow[t]{2}{*}{0,00} & \multirow[t]{2}{*}{0,18} & & & & & 0,20 \\
\hline & & & & & Stran od skole & & 0,50 & 0,00 & 0,12 \\
\hline $\begin{array}{l}\text { Osjećaj } \\
\text { nekompetentnosti }\end{array}$ &,- 129 & $-6,15$ & 0,00 & $-0,17$ & $\begin{array}{l}\text { Školska pravila i } \\
\text { dodatne aktivnosti }\end{array}$ & , 107 & 3,85 & 0,00 & 0,11 \\
\hline Uključenost u nastavi & ,096 & 4,36 & 0,00 & 0,12 & \multirow{2}{*}{$\begin{array}{l}\text { Osjećaj } \\
\text { nekompetentnosti }\end{array}$} & \multirow{2}{*}{,- 092} & \multirow{2}{*}{$-3,55$} & \multirow[t]{2}{*}{0,00} & \multirow[t]{2}{*}{$-0,10$} \\
\hline Školski uspjeh &, 065 & 3,17 & \multirow[t]{2}{*}{0,00} & \multirow[t]{2}{*}{0,09} & & & & & \\
\hline Fizičko nasilje & 058 & 301 & & & Fizičko nasilje &,- 041 & $-1,75$ & 0,08 & $-0,05$ \\
\hline Strah od škole & ,001 & ,059 & 0,95 & 0,00 & $\begin{array}{l}\text { Pohvaljivanje i } \\
\text { podrška }\end{array}$ &, 047 & 1,606 & 0,11 & 0,05 \\
\hline $\mathrm{R}=0,750, \mathrm{R}^{2}=0,562$ & 8,12 & $=196$ & 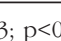 & & $\mathrm{R}=0,583, \mathrm{R}^{2}=0,3$ & $\mathrm{~F}(8$, & $0)=$ & ; p & \\
\hline
\end{tabular}

Rezultati regresijskih analiza opisuju hijerarhiju prediktora, odnosno važnost pojedinih školskih faktora u objašnjavanju konstrukta Privrženosti i Predanosti. Uz Beta pondere i njihovu značajnost, prikazane su i parcijalne korelacije $\left(\mathrm{r}_{\text {parc }}\right)$ svakog prediktora s kriterijskim varijablama. 
Najsnažniji prediktor privrženosti je pohvaljivanje i podrška. Učenici vole školu i osjećaju privrženost ukoliko u školi dobivaju visoku razinu nagrađivanja, potkrepljivanja, odnosno pohvaljivanja kojim se eksplicitno prepoznaje i priznaje njihov trud, nastojanje i uspješnosti u radu. Nadalje, snažan prediktor privrženosti je i poticajnost škole, odnosno kapacitet škole da kod učenika potiče i razvija široki raspon njegovih potencijala - korisnih znanja, vještina i vrijednosti. Za privrženost školi važnom se pokazuje i postojanje jasnih školskih pravila i normi ponašanja koja učenicima olakšavaju snalaženje i orijentaciju. Ova su pravila tijesno povezana i s ponudom dodatnih aktivnosti u školi koje učenicima omogućuju zadovoljavanje osobnih interesa. Privrženost je također povezana i s konkretnom uključenosti i aktivnim sudjelovanjem i suradnjom na nastavi i u učenju. Pozitivan je također i efekt dobrih školskih ocjena. Zaslužene dobre ocjene jačaju osjećaj sposobnosti i uspješnosti koja olakšava razvoj pozitivnog stava i pozitivnih emocija prema školi.

Snažan negativan učinak na osjećaj privrženosti ima osjećaj nekompetentnosti za školu. Uz to, negativno djeluju i iskustva fizičkog nasilja od strane vršnjaka zbog kojega se škola može doživljavati kao opasno i odbojno mjesto. Strah od škole se u ovoj konstelaciji prediktora ne javlja kao značaj prediktor privrženosti školi.

Hijerarhija važnosti prediktora je različita za predanost. Za predanost se najznačajnijim čimbenikom javljaju školske ocjene, odnosno školski uspjeh. Učenici koji iskazuju izraženiju predanost izvršavanju obveza ostvaruju i bolji uspjeh, odnosno, njihova se nastojanja nagrađuju boljim ocjenama. Značajan odnos s Predanošću imaju i poticajnost škole, uključenost učenika na nastavi i postojanje jasnih školskih pravila i zanimljivih dodatnih aktivnosti. Zanimljivo je da se značajnim pozitivnim prediktorom za predanost javlja i strah od škole. Izraženiji strah od škole povezan je s višom razinom predanosti i nastojanjem da se ostvare zahtjevi škole.

S druge strane osjećaj nekompetentnosti za školu ima obrnut utjecaj. Osjećaj nekompetentnosti djeluje demotivirajuće i snižava razinu nastojanja da se redovitim radom ostvaruje što bolji školski uspjeh.

Posebno je zanimljivo što se u ovoj regresijskoj analizi pohvaljivanje, koje je najznačajniji prediktor privrženosti, ne pokazuje značajnim prediktorom predanosti. Iako njegova osnovna korelacija s predanošću iznosi $r=0,35$, u složaju varijabli korištenih u regresijskoj analizi, njegova parcijalna korelacija s predanošću iznosi tek $\mathrm{r}_{\text {parc }}=0,05$.

\section{Rasprava}

Temeljni cilj ovoga rada bio je provjeriti valjanost konstrukata Privrženosti i Predanosti kao dimenzija vezanosti za školu i to analizom njihovih međusobnih odnosa te njihove povezanosti s pozitivnim obrazovnim ishodima i s teorijski bliskim varijablama. 
Faktorskim je analizama potvrđena čista dvofaktorska solucija čestica koje opisuju pretpostavljene faktore Privrženosti školi i Predanosti izvršavanju školskih obveza. Ovakva faktorska kompozicija u skladu je s teorijskim postavkama (Catallano i Hawkins, 1996.) i s brojnim istraživanjima (Hawkins i sur., 2001.; Lonczak i sur., 2001.; Cunningham, 2007.; Wenzel i sur., 2009.). Faktori Privrženosti i Predanosti mjerljivi su visoko pouzdanim ljestvicama koje proizlaze iz ovih faktorskih analiza.

Provedene analize upućuju na valjanosti ovih ljestvica za istraživanje ovih dviju relativno nezavisnih dimenzija vezanosti za školu (school bonding) na hrvatskom govornom području.

Potvrđena je pretpostavljena pozitivna povezanost školskog uspjeha i dimenzija vezanosti za školu. Učenici koji iskazuju višu razinu privrženosti i predanosti imaju bolje ocjene, odnosno ostvaruju bolji školski uspjeh. Rezultat potvrđuje nalaze drugih istraživanja. Bergin i Bergin (2009.) ističu da je sigurna privrženost za učitelje povezana s višim ocjenama i rezultatima na standardiziranim testovima. Učenici koji osjećaju sigurnost i prihvaćenost slobodniji su za poduzimanje intelektualnih i socijalnih izazova i za istraživanje novih ideja.

Pretpostavljena veza između dobi i vezanosti za školu samo je dijelom potvrđena. Značajne su razlike utvrđene za faktor Predanosti, ali ne i za faktor Privrženosti. Učenici različite dobi međusobno se ne razlikuju po privrženosti školi. Što se predanosti tiče, ona se smanjuje s dobi. Učenici prvih i drugih razreda srednjih škola tako iskazuju značajno višu razinu spremnosti za izvršavanje školskih obveza od učenika trećih i četvrtih razreda. Ovi podaci upućuju na postojanost emocionalne veze (privrženosti) sa školom neovisno o dobi, dok sklop uvjerenja i prihvaćanja školskih vrijednosti te $s$ time povezanih ponašanja (predanost) očito $s$ vremenom slabi. Čini se da emocionalna vezanost za nastavnike i školu nije dostatna da se pretoči i u trajnija odgovorna ponašanja koja škola od učenika traži.

Ovi su nalazi u skladu s općim shvaćanjem kako u adolescenciji slabe socijalne veze mladih s primarnim sustavima poput obitelji i škole, a jačaju utjecaji vršnjaka i šire socijalne okoline. Opadanje razine predanosti možemo objasniti i uvjetima koji prethode razvoju vezanosti, poput (ne)stvaranja prilika za aktivno sudjelovanje u školskom životu, (ne)pružanja mogućnosti za razvoj adekvatnih vještina, (ne) nagrađivanja uspjeha (Catallano i Hawkins, 1996.) ili (ne)zanimljivosti školskih programa, odnosno upitnoj razvojnoj primjerenosti i općoj strukturiranosti srednjoškolskog okruženja koje značajno smanjuje mogućnosti za razvoj čvršće vezanosti. Lee i Smith (2001.) smatraju kako se u srednjim školama, zbog njihove veličine i "birokratiziranosti" nastave narušava osjećaj zajedništava između nastavnika i učenika, a koji je bio snažnije prisutan u osnovnoj školi. Učenici nemaju toliko prilika bolje upoznati svoje nastavnike, formirati mentorski odnos i uopće stvoriti pozitivan odnos s važnijom odraslom osobom izvan obiteljskog okruženja. Rezultat toga je međusobno nepovjerenje i udaljavanje od zajedničkih vrijednosti i ciljeva školskog obrazovanja, što smanjuje uključenost u obrazovni proces i motivaciju 
učenika. Negativan trend smanjivanja privrženosti i predanosti uočljiv u našem ispitivanju

O konceptualnoj različitosti ispitanih konstrukata svjedoči i analiza rodnih razlika privrženosti i predanosti. Naši rezultati upućuju na minimalne razlike u privrženosti djevojaka i mladića, no istovremeno djevojke iskazuju značajno izraženiju predanost od mladića.

Ovakvi su nalazi u skladu s drugim istraživanjima koja navode Maddox i Prinz (2003.), a koja se bave rodnim razlikama u procjeni pojedinih dimenzija vezanosti za školu. Djevojke su u prosjeku značajno više predane i posvećene učenju, neovisno o emocionalnoj vezi koju ostvaruju u školi.

Potrebno je međutim naglasiti da i rodne razlike ovise o tipu škole koje učenici pohađaju. Značajno veću predanost iskazuju djevojke u četverogodišnjim strukovnim školama i gimnazijama od djevojaka u trogodišnjim strukovnim školama. Kod muškaraca, gimnazijalci iskazuju značajno višu razinu predanosti od učenika strukovnih škola koji se međusobno ne razlikuju.

Odnos privrženosti i predanosti s ostalim relevantnim "školskim" varijablama ispitan je usporedivim regresijskim analizama pri kojima je korišten identičan set "prediktorskih" varijabli za obje "kriterijske" varijable. Utvrđeni su razmjerno visoki koeficijenti multiple korelacije između Privrženosti $(R=0,75)$ i Predanosti $(R=0,583)$ i seta "Školskih varijabli" koje dobro korespondiraju s konstruktima iz modela socijalnog razvoja (Catallano i Hawkins, 1996.), a koji prema teoriji prethode razvoju vezanosti za školu.

Detaljnija analiza odnosa školskih varijabli i dviju dimenzija vezanosti za školu otkriva još nekoliko zanimljivih nalaza. Učenici vole školu i osjećaju privrženost školi ukoliko u njoj dobivaju dostatnu razinu nagrađivanja i potkrepljivanja, ukoliko škola kod njih potiče i razvija široki raspon znanja, vještina i pozitivnih vrijednosti te ukoliko postoje jasna školska pravila ponašanja. Ovi su nalazi također u skladu s pretpostavljenim teorijskim odnosima Catalana i Hawkinsa (1996.).

Za razliku od privrženosti, za predanost se najznačajnijim čimbenikom javljaju školske ocjene, poticajnost škole te uključenost učenika na nastavi. Zanimljivo je da se pohvaljivanje, koje je najznačajniji prediktor privrženosti, ne pokazuje značajnim prediktorom predanosti, dok se izraženiji strah od škole pokazao značajno povezanim s višom razinom predanosti. Ovaj podatak otvara pitanje o podlozi motivacijskih procesa za učenje u našim srednjim školama. Izgleda da je određena doza straha od škole, nastavnika i roditeljskih reakcija važan motivacijski čimbenik koji navodi učenika na savjesnije izvršavanje školskih obveza.

S druge strane osjećaj nekompetentnosti za školu negativno je povezan s obje dimenzije vezanosti za školu. Osjećaj nekompetentnosti za školu i izvršavanje školskih obveza razvija se u školskom kontekstu i važan je aspekt negativnog 
samopoimanja učenika. Fokusiranje na neuspjeh demotivira, jača osjećaj bespomoćnosti koji obeshrabruje i odbija učenika od škole i učenja. Ovakav je nalaz u skladu s tzv. "stage-enviroment fit" modelom kojega opisuju Eccles i sur. (1993.). Autori navode kako je za uspješan socijalni, emocionalni i kognitivni razvoj djeteta važno da škola u svojem ukupnom okruženju i zahtjevima odgovara djetetovim razvojnim potrebama i njegovim/njenim mogućnostima. Ovaj podatak govori o važnosti pozitivnog potkrepljivanja i usmjerenosti na pozitivne potencijale svakog učenika. Autori ukazuju na jasnu vezu između uvjerenja učenika da može savladati obrazovni program, njegove stvarne angažiranosti u tom procesu i konačnog uspjeha.

Fizičko zlostavljanje u ovom radu reprezentira dimenziju nesigurnosti i ugroženosti u školi te je opravdano pretpostaviti da se negativno odražava na vezanost za školu kao pozitivni emocionalni i motivacijski odnos. U našim se analizama fizičko zlostavljanje pokazalo značajnim za privrženost, ali ne i za predanost, što opet ukazuje na koncepcijsku različitost ovih dviju dimenzija. Nalaz je u skladu s istraživanjem Cunningham (2007.) koje pokazuje da se nasilnici u školi često osjećaju dobro vezanima za školu kada ih nitko u nasilničkom ponašanju ne ograničava i ne poziva na odgovornost, dok žrtve koje iskuse izostanak zaštite odraslih osoba školu doživljavaju kao opasno mjesto te stoga ne osjećaju bliskost s takvim sustavom. Ova iskustva fizičkog nasilja ne odnose se i na predanost, koja je ipak prvenstveno vezana uz izvršavanje školskih zadataka koji se moraju odrađivati.

\section{Zaključci}

Osnovna je zadaća škole je voditi brigu o djeci i osiguravati im optimalnu podršku u njihovom osobnom i socijalnom razvoju. U tom je kontekstu posebno važno da škola stvara uvjete kako bi se kod učenika razvijala i ustalila sigurna privrženost i predanost učenika pozitivnim školskim vrijednostima. Prema našim rezultatima, a i shvaćanjima brojnih autora (Bergin i Bergin, 2009.), iznimno je važna uloga nastavnika i same organizacije škole. Što se nastavnika tiče, najvažniji čimbenici su topla i podržavajuća interakcija s učenicima, pružanje podrške autonomiji učenika, promoviranje prosocijalnog ponašanja, dobra pripremljenost za nastavu i visoka, ali realistična očekivanja od učenika. Organizacija škole bi morala uključivati optimalno poticanje svih potencijala učenika, od širokih do specifičnih znanja i vještina, jačanja samostalnog i kritičkog mišljenja, preko boljeg razumijevanje samoga sebe i drugih ljudi, do razvoja osobnog morala i etičkog rezoniranja i ostvarivanja građanskih prava. Naši rezultati istovremeno potvrđuju važnost postojanja jasnih i dosljednih pravila ponašanja i disciplinskih mjera u školi, kao i važnost ponude zanimljivih i poticajnih dodatnih (ekstrakurikulanih) aktivnosti. Istovremeno škola mora odstraniti postupke koji vode osjećaju nekompetentnosti i negativnom samopoimanju učenika, te provoditi trajne, aktivne i široko postavljene školske preventivne programe radi sprečavanja ponašanja nastavnika i učenika koji bi mogli ugrožavati pozitivnu i sigurnu vezanost učenika za školu. 
Ograničenje ovog istraživanja je svakako korelacijski nacrt koji ne dopušta zaključivanje o uzročno posljedičnoj vezi između promatranih varijabli. Analiza razlika između škola otežana je činjenicom da unutar jedne ustanove često djeluju različiti trogodišnji, četverogodišnji pa i gimnazijski programi koje provode različiti nastavnici. Za potpuniju analizu vezanosti za školu bilo bi dobro višegeneracijsko praćenje i verificiranje uočenih odnosa. Također je važno razlučiti efekte koji proizlaze iz sociodemografske kompozicije škole koji ovdje nisu bili ispitani, od školskih efekata, jer socijalno okruženje iz kojega učenici dolaze također može značajno utjecati na vezanost za školu.

Neposredna korist od ovog istraživanja je da ono jasno ističe čimbenike važne za jačanje privrženosti i predanosti školi. Riječ je o značajnim zaštitnim čimbenicima za razvoj rizičnih ponašanja, ali potencijalnom prostoru za intervenciju u školskom okruženju. Najveću korist od istraživanja mogu imati same škole, s obzirom da su prikazani mjerni postupci jednostavni i prikladni za primjenu u školskom kontekstu za samoanalizu i samovrednovanje škola.

\section{Literatura}

1. Abbott, R. D. \& O'Donnell, J. (1998). Changing teaching practices to promote achivement and bonding to school. American Journal of Orthopsychiatry, 68(4):542-552.

2. Bergin, C. \& Bergin, D. (2009). Attachment in the classroom. Educational Psychology Review, 21(2):141-170.

3. Bezinović, P. (Ur.) (2010). Samovrednovanje škola: Prva iskustva u osnovnim školama. Zagreb: Agencija za odgoj i obrazovanje/Institut za društvena istraživanja u Zagrebu.

4. Catalano, R. F. i Hawkins, J. D. (1996). The social development model: A theory of antisocial behaviour, In: Hawkins, J. D. (Ed.). Delinquency and crime: Current theories. New York: Cambridge University Press.

5. Cernkovich, S. A. \& Giordano, P. C. (1992). School bonding, race, and delinquency. Criminology, 30:261-291.

6. Cunningham, N. J. (2007). Level of Bonding to School and Perception of the School Environment by Bullies, Victims, and Bully Victims. The Journal of Early Adolescence, 27:457-478.

7. Eccles, J. S.; Midgley, C.; Wigfield, A.; Buchanan, C. M.; Reuman, D.; Flanagan, C.; MacIver, D. (1993). Development during adolescence: The impact of stage-environment fit on adolescents' experiences in schools and families. American Psychologist, 48:90-101.

8. Eccles, J. S. \& Roeser, R. W. (2003). Schools as Developmental Contexts, u: Adams, G. R. i Berzonsky, M. D. (Eds). Blackwell Handbook of Adolescence. Oxford: Blackwell publishing.

9. Etički kodeks istraživanja s djecom (2003). Zagreb: Državni zavod za zaštitu obitelji, materinstva i mladeži.

10. Fulgosi, A. (1979). Faktorska analiza. Zagreb: Školska knjiga.

11. Hawkins, J. D.; Guo, J.; Hill, K. G.; Battin-Pearson, S.; Abbott, R. D. (2001). Long-Term Effects of the Seattle Social Development Intervention on School Bonding Trajectories. Applied Developmental Science, 5(4):225-236.

12. Hirschi, T. (1969). Causes of delinquency. Berkeley: University of California Press. 
13. Hu, L. T. \& Bentler, P. M. (1998). Fit indices in covariance structure modeling: sensitivity to underparameterized model misspecification. Psychological Methods, 3:424-453.

14. Klem, A. M. \& Connell, J. P. (2004). Relationships matter: linking teacher support to student engagement and achievement. Journal of School Health, 74(7):262-273.

15. Kuzman, M., Pejnović Franelić, I. i Pavić Šimetin, I., M. (2008). Ponašanje u vezi sa zdravljem u djece školske dobi 2005-2006. Zagreb: Hrvatski zavod za javno zdravstvo.

16. Lee, V. E. \& Smith, J. (2001). Restructuring high schools for equity and excellence: What works. New York: Teachers College Press.

17. Libbey, H. P. (2004). Measuring Student Relationships to School: Attachment, Bonding, Connectedness, and Engagement. Journal of School Health, 74(7):274-283.

18. Lonczak, H. S.; Huang, B.; Catalano, R. F.; Hawkins, J. D.; Hill, G. H.; Abbott, R. D.; Ryan, J. A. M.; Kosterman, R. (2001). The Social Predictors of Adolescent Alcohol Misuse: A Test of the Social Development Model. Journal of Studies on Alcohol, 62(2):179-189.

19. Maddox, J. S. \& Prinz, R. J. (2003). School Bonding in Children and Adolescents: Conceptualization, Assessment, and associated Variables. Clinical Child and Family Psychology Review, 6(1):31-49.

20. Mcgee, Z. T. (1992). Social class differences in the parental and peer influence on adolescent drug use. Deviant Behavior, 13:349-372.

21. Miharija, M. i Kuridža B. (2010). Mišljenja i stavovi djece i mladih u Hrvatskoj. Zagreb: UNICEF, Ured za Hrvatsku.

22. Murray, C. \& Greenberg, M. (2000). Children's relationship with teachers and bonds with school: An investigation of patterns and correlates in middle childhood. Journal of School Psychology, 38:423-445.

23. Murray, C. \& Greenberg, M. (2001). Relationships with teachers and bonds with school: Social emotional adjustment correlates for children with and without disabilities. Psychology in the Schools, 38:25-41.

24. Simons-Morton, B. G.; Crump, A. D.; Haynie, D. L.; Saylor, K. E. (1999). Student-school bonding and adolescent problem behavior. Health Education Research, 14:99-107.

25. Sun, J. (2005). Assessing Goodness of Fit in Confirmatory Factor Analysis. Measurement and Evaluation in Counseling and Development, 37:240-256.

26. Thompson, D. R.; Iachan, R.; Overpeck, M.; Ross, J. G.; Gross, L. A. (2006). School connectedness in the health behaviour in school aged children study: the role of student, school, and school neighbourhood characteristics. Journal of School Health, 76(7):379386.

27. Waters, S. K., Cross, D. S. \& Runions, K. (2009). Social and Ecological Structures Supporting Adolescent Connectedness to School: A Theoretical Model. The Journal of School Health, 79(11):516-524.

28. Wenzel, V., Weichold, K. \& Silbereisen, R. K. (2009). The life skills program IPSY: positive influences on school bonding and prevention of substance misuse. Journal of Adolescence, 32(6):1391-1401. 
Original scientific work

\author{
Darko Roviš \\ School of Medicine in Rijeka \\ darko.rovis@zzjzpgz.hr \\ Petar Bezinović \\ Institute for Social Research in Zagreb \\ petar@idi.hr
}

\title{
School Bonding - an Analysis of Attachment to School and Commitment to Schooling in High School Students
}

\begin{abstract}
School bonding could be defined through various relations students have with their school, teachers, values and norms that school promotes. As such it is a strong protective factor for risk behaviour that violates such school norms.

The aim of this study was to verify the attachment to school and the commitment to schooling as the two fundamental dimensions of school bonding. Two measuring scales were prepared in accordance with the conceptualization of Maddox and Prinz (2003). Data were collected on a sample of 1927 students of all secondary schools in the Primorsko-Goranska County.
\end{abstract}

Two-dimensional construct was confirmed by factor analysis. The coefficient of reliability (Cronbach alpha) for the Attachment scale of ten items was 0.87 , while the reliability of the Commitment scale of seven items was 0.86. Their conceptual differences were compared by two separate regression analysis with a list of predictor variables that examined the students' relationship to school. The measures were also tested with regard to academic achievement, gender and type of school that students attend. Students who achieve better school grades show a higher level of attachment and commitment, while students of different types of schools do not differ significantly in their attachment to school, but they differ significantly in the commitment to carrying out school obligations. Girls and grammar school students reported a higher level of commitment to carrying out the school obligations, compared to students in vocational schools.

The analysis carried out confirms the validity of the developed scales and their usefulness for further research of school bonding in Croatian language.

Key words: school bonding, attachment to school, school commitment. 
Prilog

Struktura glavnih komponenti tvrdnji (ljestvica) korištenih u istraživanju

\begin{tabular}{|c|c|c|c|c|c|c|c|}
\hline UTJECAJ ŠKOLE & $\mathrm{F} 1$ & $\mathrm{~F} 2$ & F3 & $\mathrm{F} 4$ & F5 & F6 & F7 \\
\hline \multicolumn{8}{|l|}{ Poticajnost škole $(\alpha=0,88)$} \\
\hline $\begin{array}{l}\text { Razvoj osobnog morala, etičkog sustava vrijednosti } \\
\text { (poštenja) }\end{array}$ &, 70 & & & & & & \\
\hline Jasno i dobro usmeno i pismeno izražavanje &, 69 & & & & & & \\
\hline Samostalno i kritičko razmišljanje &, 68 & & & & & & \\
\hline Uspješno surađivanje s drugima &, 67 & & & & & & \\
\hline Razumijevanje i bolje upoznavanje samoga sebe &, 66 & & & & & & \\
\hline Bolje razumijevanje drugih ljudi &, 65 & & & & & & \\
\hline Vještine učenja, kako uspješno samostalno učiti &, 61 & & & & & & \\
\hline Široka opća znanja &, 59 & & & & & & \\
\hline $\begin{array}{l}\text { Ostvarivanje građanskih prava (razumijevanje demokracije, } \\
\text { politike i sl.) }\end{array}$ &, 55 & & & & & & \\
\hline Upoznavanje s prirodnim zakonitostima &, 54 & & & & & &, 36 \\
\hline Analiziranje numeričkih problema (računanje) &, 51 & & & & & &, 31 \\
\hline Upotreba kompjutera i Interneta &, 50 & & & & & & \\
\hline Znanja i vještine koje su važne za moju struku &, 49 & & & & & & \\
\hline \multicolumn{8}{|l|}{ Pohvaljivanje i podrška $(\alpha=0,85)$} \\
\hline $\begin{array}{l}\text { Kad u školi imam dobru ideju ili pokažem inicijativu to se } \\
\text { prepoznaje i bivam pohvaljen }\end{array}$ & &, 73 & & & & & \\
\hline $\begin{array}{l}\text { Kad u školi uspješno izvršim zadatak ili kad ostvarim neki } \\
\text { uspjeh dobivam pohvalu od nastavnika }\end{array}$ & &, 72 & & & & & \\
\hline Nastavnici me nagrade kad uložim poseban trud & &, 68 & & & & & \\
\hline $\begin{array}{l}\text { Nastavnici me potiču na inicijativu i angažman u nastavi i } \\
\text { izvan nastave }\end{array}$ & &, 67 & & & & & \\
\hline $\begin{array}{l}\text { Učeničko udruživanje i timski rad se posebno cijeni u našoj } \\
\text { školi }\end{array}$ & &, 63 & & & & & \\
\hline $\begin{array}{l}\text { Kad u školi uspješno izvršim zadatak ili kad ostvarim neki } \\
\text { uspjeh nastavnici o tom izvijeste moje roditelje }\end{array}$ & &, 57 & & & & & \\
\hline $\begin{array}{l}\text { S nastavnicima raspravljamo o našim idejama u vezi } \\
\text { s nastavom i izvannastavnim aktivnostima i zajedno } \\
\text { odlučujemo }\end{array}$ & &, 55 & & & & & \\
\hline Nastavnici su mi potpora u realizaciji mojih ideja i inicijativa & &, 54 & & & & & \\
\hline \multicolumn{8}{|l|}{ Strah od škole $(\alpha=0,83)$} \\
\hline Bojim se ispitivanja & & &, 79 & & & & \\
\hline Bojim se neuspjeha u školi & & &, 77 & & & & \\
\hline Jako me pogađa kada dobijem lošu ocjenu & & &, 72 & & & & \\
\hline Loše me ocjene obeshrabruju za daljnje učenje & & &, 70 & & & & \\
\hline Nastavnici u meni izazivaju strah & & &, 70 & & & & \\
\hline Bojim se roditeljskih reakcija na moje ocjene & & &, 63 & & & & \\
\hline
\end{tabular}




\begin{tabular}{|c|c|c|c|c|c|c|c|}
\hline UTJECAJ ŠKOLE & $\mathrm{F} 1$ & $\mathrm{~F} 2$ & F3 & $\mathrm{F} 4$ & F5 & F6 & F7 \\
\hline \multicolumn{8}{|l|}{ Uključenost učenika u nastavi i učenju $(\alpha=0,74)$} \\
\hline $\begin{array}{l}\text { S učenicima iz razreda sam i izvan nastave surađivao na } \\
\text { školskim zadacima }\end{array}$ & & & & ,68 & & & \\
\hline $\begin{array}{l}\text { Na nastavi sam prezentirao dio gradiva (referat, samostalni } \\
\text { rad i sl.) }\end{array}$ & & & & ,66 & & & \\
\hline $\begin{array}{l}\text { Na samoj nastavi sam u grupi radio s drugim učenicima na } \\
\text { nekom zadatku }\end{array}$ & & & & ,63 & & & \\
\hline $\begin{array}{l}\text { Na nastavi sam postavljao pitanja i sudjelovao u grupnim } \\
\text { raspravama }\end{array}$ & & & & ,63 & & & \\
\hline $\begin{array}{l}\text { Pomagao sam drugim učenicima u učenju i razumijevanju } \\
\text { gradiva }\end{array}$ & & & &, 59 & & & \\
\hline $\begin{array}{l}\text { Raspravljao sam o nastavi, ispitivanju i ocjenama s } \\
\text { nastavnicima }\end{array}$ & & & &, 41 & & & \\
\hline S nastavnicima sam i izvan nastave raspravljao o gradivu & & & &, 39 & & & \\
\hline \multicolumn{8}{|l|}{ Osjećaj nekompetentnosti za školu $(\alpha=0,78)$} \\
\hline Školske obveze su za mene preteške & & & & &, 76 & & \\
\hline Školski program je prezahtjevan za mene & & & & &, 75 & & \\
\hline Imam problema s razumijevanjem gradiva & & & & &, 74 & & \\
\hline Mislim da nisam dovoljno sposoban za ovu školu & & & & &, 70 & & \\
\hline Razmišljam o prestanku školovanja & & & & &, 52 & & \\
\hline \multicolumn{8}{|l|}{ Iskustva fizičkog zlostavljanja $(\alpha=0,74)$} \\
\hline Netko me je fizički napao u školi & & & & & &, 81 & \\
\hline U školi su mi neki učenici prijetili da će me istući & & & & & &, 80 & \\
\hline Drugi učenici su me fizički maltretirali (gurkali, tukli i sl.) & & & & & &, 75 & \\
\hline U školi su mi ukrali novce ili neke stvari & & & & & & ,49 & \\
\hline Doživio sam nezgodu, ozlijedio sam se u školi & & & & & &, 48 & \\
\hline \multicolumn{8}{|l|}{ Školska pravila i dodatne aktivnosti $(\alpha=0,74)$} \\
\hline $\begin{array}{l}\text { U školi ima dovoljno izvannastavnih aktivnosti u koje se } \\
\text { mogu uključiti }\end{array}$ & & & & & & &, 75 \\
\hline Sviđaju mi se ponuđene izvannastavne aktivnosti & & & & & & &, 73 \\
\hline $\begin{array}{l}\text { Školski program i ponuđene aktivnosti odgovaraju mojim } \\
\text { potrebama }\end{array}$ & & & & & & & ,62 \\
\hline $\begin{array}{l}\text { Školska pravila i disciplinske mjere se primjenjuju dosljedno } \\
\text { i pošteno }\end{array}$ & &, 36 & & & & & ,43 \\
\hline U školi postoje jasna pravila ponašanja i disciplinske mjere & & & & & & & ,39 \\
\hline \multicolumn{8}{|c|}{$\begin{array}{l}\text { Napomene: } \\
\text { Metoda ekstrakcije: Analiza glavnih komponenti; Metoda rotacije: Varimax s Kaiserovom normalizacijom. } \\
\text { Kriterij za broj ekstrahiranih faktora: Guttman-Kaiser. } \\
\text { U matrici su prikazani samo koeficijenti veći od } 0,30 \text {. }\end{array}$} \\
\hline
\end{tabular}

